\title{
Analisis Pengaruh Dana Pihak Ketiga, Pembiayaan, Bancassurance Terhadap Laba Dan Dampaknya Pada Kesejahteraan Masyarakat (Studi Kasus Bank Syariah Di Indonesia)
}

\author{
Dian Adila Putra \\ Pascasarjana UIN Sumatera Utara Medan \\ dianmetrix@gmail.com \\ Marliyah \\ Pascasarjana UIN Sumatera Utara Medan \\ marliyah@uinsu.ac.id \\ Muhammad Yafiz \\ Pascasarjana UIN Sumatera Utara Medan \\ muhammad.yafiz@uinsu.ac.id
}

\begin{abstract}
This study aims to determine how the direct influence of deposits, financing and bancassurance on the profits of Islamic banks and the welfare of society and indirect influence or through the intervening variables of profits on the welfare of society and total influence. This type of research is quantitative research. Data collection methods used are documentation methods based on data in the form of monthly financial statements for the period 2014-2018 and per capita income data that has been published. The method of data analysis in this study is by using the path analysis method. The results of the study show that financing significantly affects earnings while third party funds and bancassurance do not directly affect earnings. Deposits and profits of Islamic banks significantly influence directly on public welfare and bancassurance negatively influences people's welfare while financing does not. Financing indirectly significantly influences welfare through profit variables, whereas DPK and bancassurance do not. Business activities of Islamic banks have a role in addition to achieving company profits, also have a positive impact on the welfare of the Indonesian people. Funding and third party funds that generate profits are a determining factor for improving community welfare rather than bancassurance sales.
\end{abstract}

Keywords: Third Party Funds, Financing, Bancassurance, Profit, Community

Welfare.

\begin{abstract}
Abstrak
Penelitian ini bertujuan untuk mengetahui bagaimana pengaruh langsung DPK, pembiayaan dan bancassurance terhadap laba bank syariah dan kesejahteraan masyarakat serta pengaruh tidak langsung atau melalui variabel intervening laba terhadap kesejahteraan masyarkat dan pengaruh total. Jenis penelitian ini adalah penelitian kuantitatif. Metode pengumpulan data yang digunakan yaitu metode dokumentasi berdasarkan data-data berupa laporan keuangan bulanan periode 2014-2018 dan data pendapatan perkapita yang telah dipublikasikan. Metode analisis data dalam penelitian ini yaitu dengan menggunakan metode analisis jalur. Hasil penelitian menunjukkan bahwa pembiayaan signifikan mempengaruhi laba sedangkan dana pihak ketiga dan bancassurance tidak berpengaruh langsung terhadap laba.DPK dan laba bank syariah signifikan mempengaruhi langsung terhadap kesejahteraan masyarakat dan bancassurance secara negatif mempengaruhi kesejahteraan masyarakat sedangkan pembiayaan tidak. Pembiayaan secara tidak langsung signifikan mempengaruhi kesejahteraan
\end{abstract}


melalui variabel laba, sedangkan DPK dan bancassurance tidak. Kegiatan usaha bank syariah memiliki peran di samping untuk meraih profit perusahaan, juga berdampak positif bagi kesejahteraan masyarakat Indonesia. Pembiayaan dan DPK yang menghasilkan laba merupakan factor penentu untuk meningkatkan kesejahteraan masyarakat ketimbang penjualan bancassurance.

Kata Kunci: Dana Pihak Ketiga, Pembiayaan, Bancassurance, Laba, Kesejahteraan Masyarakat.

\section{Pendahuluan}

Indonesia adalah negara yang menjadikan kesejahteraan bangsanya sebagai tujuannya. Hal tersebut dituangkan dalam pembukaan UUD 1945 yaitu memajukan kesejahteraan umum, mencerdaskan kehidupan bangsa, dan ikut melaksanakan ketertiban dunia yang berdasarkan kemerdekaan, perdamaian abadi dan keadilan sosial. ${ }^{1}$ Selain itu, komitmen tersebut juga terjabarkan dalam batang tumbuhnya yakni bab XIV pasal 33 tentang perekonomian nasional dan kesejahteraan sosial ${ }^{2}$. Oleh karenanya, ciri dari tercapainya tujuan tersebut menurut Bung Karno dalam buku lahirnya Pancasila adalah tidak adanya kemiskinan. Untuk memastikannya para pendiri bangsa ini menegaskan dalam pasal 34 tentang fakir miskin dan anak-anak terlantar yang dipelihara oleh negara $^{3}$. Untuk mencapai tujuan tersebut negara menciptakan good governence melalui praktek penyelenggaraan kekuasaan dan kewengangan oleh pemerintah dalam pengelolaan urusan kepemerintahan secaraumum dan pembangunan ekonomi khususnya.

Kesejahteraan telah dipersepsikan sebagai sebuah pertumbuhan yang tinggi dalam pembangunan ekonomi. Pendekatan ini telah banyak membuat negara berhasil mencapainya. Indikator keberhasilan tersebut adalah meningkatnya akumulasi kapital dan pendapatan perkapita. Islam pada masa Rasulullah SAW membangun kota madinah membuat langkah untuk menciptakan kesejahteraan dan menciptakan kesetaraan dan keadilan dalam membangun perekonomian dengan mempersaudarakan kaum muhajirin dan anshar. Ikatan persaudaraan tersebut mendorong rasa untuk mendahulukan orang lain daripada dirinya sendiri, mereka saling mengasihi, saling memberi pertolongan, dan bantuan antara satu sama lain ${ }^{4}$.Sehingga tidak terjadi kesenjangan kesejahteraan diantara masyarakat Madinah dalam hal ekonomi. Disamping itu, pemberian modal untuk modal kerja berbasis bagi hasil, seperti mudharabah, muzara'ah, 
musaqah telah dikenal diantara kaum muhajirin dan anshar sebagai bentuk persaudaraan umat muslim. ${ }^{5}$ Rasulullah juga membentuk baitul maal, sebuah institusi yang bertindak sebagai pengelola keuangan. Baitul maal ini memegang peranan yang sangat penting bagi perekonomian, termasuk dalam melakukan kebijakan yang bertujuan untuk kesejahteraan masyarakat ${ }^{6}$.

Di negara Indonesia berbagai cara, metode, aturan, alat, pendekatan ditempuh untuk mencapai tujuan mensejahterakan masyarakat dan pembangunan ekonomi, salah satunya dengan didirikan suatu bank syariah pada tahun 90-an. Hal ini dilakukan untuk membantu pemerintah dalam bidang pembangunan ekonomi dan keuangan yaitu untuk melancarkan program program investasi, lalu lintas pembayaran dan menghidupkan sektor rill melalui pembiayaan sehingga diharapakan dapat menambah PDB (Produk Domestik Bruto) suatu negara yang dapat berdampak pada pertumbuhan ekonomi sehingga tujuan negara untuk mensejahterakan masyarakat dapat terealisasi dengan baik.

Namun lembaga keuangan syariah terutama bank syariah/Islam walaupun selama ini dianggap sebagai faktor penghambat pembangunan (an obstacle to economic growth $)^{7}$ diharapkan dapat mewujudkan tujuan pendirian suatu bank sesuai dengan Undang Undang No. 10 tahun 1998 pasal 1 " Bank adalah Badan Usaha yang menghimpun dana dari masyarakat dalam bentuk simpanan dan menyalurkannya kepada masyarakat dalam bentuk kredit dan/atau dalam bentuk lainnya dalam rangka meningkatkan taraf hidup rakyat. ${ }^{8}$ Kemudian ditegaskan kembali tujuan utama dari berdirinya bank syariah pada Undang undang No. 21 tahun 2008 pasal 3 yaitu " Perbankan Syariah bertujuan menunjang pelaksanaan pembangunan nasional dalam rangka meningkatkan keadilan, kebersamaan, dan pemerataan kesejahteraan rakyat". 9 Hind Lebdaoui dan Joerg Wild dalam penelitiannya mengemukakan bahwa perbankan Islam terkhusus di daerah dengan penduduk mayoritas muslim akan berpengaruh pada pertumbuhan ekonomi dan berkontribusi pada stabilitas keuangan di daerah tersebut namun jangka panjang. ${ }^{10}$

Bank syariah melakukan aktifitas penghimpunan dana dari masyarakat dalam bentuk dana pihak ketiga. Dana dari masyarakat ini akan meningkat utility (daya guna) Para penabung menyimpan uangnya di lembaga keuangan. Uang tersebut dalam persentase tertentu ditingkatkan kegunaanya oleh lembaga keuangan dan memberikan keuntungan bagi nasabah dan tentunya menambah pendapatan nasabah dan tingkat kesejahteraannya. ${ }^{11}$ kemudian menyalurkannya 
dalam bentuk pembiayaan baik itu modal kerja, investasi dan juga konsumsi, karena sumber utama profitability bank adalah pembiayaan, selain itu pembiayaan juga bertujuan meningkatkan usaha nasabah, menimbulkan gairah usaha, sebagai alat stabilitas ekonomi dan tentunya sebagai jembatan untuk peningkatan pendapatan nasional dan berdampak pada peningkatan kesejahteraan masyarakat ${ }^{12}$ Dengan berkembangnya produk dan persaingan perbankan syariah saat ini. Untuk lebih meningkatkan profitabilitas bank syariah juga menawarkan jasa jasa keuangan yang arah bisnis yang cendrung meningkatkan feebased income. diantaranya meningkatkan biaya administrasi tabungan, jasa jasa keuangan (transfer, LLG, RTGS), payment point, LC, Bank Garansi dan yang populer saat ini penjualan bancassurance. Bancasurrance merupakan layanan Bank dalam menyediakan produk asuransi yang memberi perlindungan jiwa dan produk investasi untuk memenuhi kebutuhan finansial jangka panjang nasabah. ${ }^{13}$ dibeberapa bank syariah lebih mengutamakan penjualan bancassurance di banding kegiatan penghimpunan dan penyaluran dana. Hal ini dilakukan karena pendapatan yang dihasilkan dari bancassurance langsung menjadi laba dan memiliki resiko rendah terhadap stabilitas dan kelangsungan operasional bank. Seperti di bank sinarmas syariah sales scorcard untuk bancassurance memiliki bobot lebih tinggi dari pada funding atau financing, pencapaian deposito 5 Milyar memiliki bobot yang sama dengan pencapaian bancassurance hanya 10 juta saja. ${ }^{14}$ Hal ini dikritisi oleh Mulyanto pada saat pembukaan Bank Sinarmas Syariah Cabang Medan. Menurut beliau, "Bank syariah tidak boleh hanya mengedepankan penjualan bancassurance tanpa gencar untuk menyalurkan pembiayaan, bahkan stop pembiayaan. Karna pembiayaan lebih berdampak pada pertumbuhan ekonomi dan kesejahteraan masyarakat Indonesia." ${ }^{15}$ Dari latar belakang tersebut penulis tertarik mengangkat judul tesis yaitu : "Analisis Pengaruh Dana Pihak Ketiga (DPK), Pembiyaan, Bancassurance terhadap Laba dan dampaknya terhadap Kesejahteraan Masyarakat "Studi Kasus Bank Syariah Indonesia ."

\section{Landasan Teori}

KesejahteraanMasyarakat 
Dalam ekonomi kesejahteraan dihubungkan dalam kuntungan benda dan menunjuk pada jangakauan pelayanan untuk memenuhi kebutuhan masyarakat. Untuk menciptakan kesejahteraan di tentukan beberapa indikator:

a. Jumlah dan pemerataan pendapatan. Pendapatan berhubungan dengan lapangan kerja, kondisi usaha, dan factor ekonomi lainnya. Penyediaan lapangan kerja mutlak dilakukan oleh semua pihak agar masyarakat memiliki pendapatan tetap untuk memenuhi kebutuhan hidupnyan. Tanpa itu semua, mustahil manusia dapat mencapai kesejahteraan. Kesempatan kerja dan kesempatan berusaha diperlukan agar masyarakat mampu memutar roda perekonomian yang pada akhirnya mampu meningkatkan jumlah pendapatan yang mereka terima.

b. Pendidikan yang semakin mudah untuk dijangkau.

c. Kualitas kesehatan yang semakin meningkat dan merata.

Untuk mencapai indikator kesejahteraan masyarakat ini dapat di ukur dari pertumbuhan ekonomi suatu negara. Pertumbuhan ekonomi secara umum dapat ditunjukkan oleh angka Produk Domestik Bruto (PDB), Investasi,Inflasi,pajak dan retribusi, pinjaman dan pelayanan bidang ekonomi. Khusus untuk nilai Produk Domestik Bruto (PDB) secara nyata mampu memberikan gambaran mengenai nilai output bruto yang dihasilkan suatu perekonomian dari unit-unit produksi pada suatu Negara dalam periode tertentu. ${ }^{16}$ Besarnya PDB merupakan gambaran awal tentang produktifitas dan tingkat kemakmuran suatu negara. Alat ukur yang disepakati tentang tingkat kemakmuran adalah PDB/output nasional per kapita. nilai output/PDB per kapita diperoleh dengan cara membagi besarnya PDB dengan jumlah penduduk pada tahun yang bersangkutan. Jika angka PDB perkapita semakin besar, maka tingkat kemakmuran dianggap makin tinggi. ${ }^{17}$

Dalam Islam pemerintahan yang dibangun Rasulullah SAW di madinah mampu menciptakan suatu aktivitas perekonomian yang maju. Rasulullah Saw memperkenalkan sistem ekonomi Islam. Hal ini berawal dari mempersaudarakan dan kerjasama antara kaum anshar dan muhajirin. Sistem ekonomi islam diperkenalkan antara lain, syirkah, qiradh dan khiyar dalam perdagangan. Selain itu, diperkenalkan sistem jual beli almurabahah, musaqah, mukhabarah, dan muzaraah dalam bidang pertanian dan perkebunan. Bahkan didalam sejarah perekonomian umat islam pembiayaan yang dilakukan dengan akad syariah telah menjadi tradisi umat islam pada zaman rasulullah saw, praktik seperti menerima 
titipan harta, meminjamkan uang untuk keperluan konsumsi dan untuk keperluan bisnis serta melakukan pengiriman uang. ${ }^{18}$

\section{Laba}

laba adalah kompensasi atas risiko yang ditanggung oleh perusahaan. Makin besar risiko, laba yang diperoleh harus semakin besar. Laba atau keuntungan adalah nilai penerimaan total perusahaan dikurangi biaya total yang dikeluarkan perusahaan. ${ }^{19}$ Menurut Zainul Arifin dalam bukunya Manajemen Bank Syariah, "Ada beberapa faktor yang mempengaruhi laba bank syariah diantaranya segmentasi bisnis, tingkat pengembalian, margin keuntungan, manajemen dana bank, biaya operasional dan pangsa pasar. Laba berperan sebagai salah satu faktor untuk menarik pihak investor untuk menanamkan modalnya kepada perusahaan. sehingga perusahaan dapat melakukan ekspansi bisnis dan menyerap tenaga kerja sehingga meningkatkan pertumbuhan ekonomi dan kesejahteraan masyarakat. ${ }^{20}$

\section{Dana Pihak Ketiga (DPK)}

Dana yang berasal dari masyarakat baik itu dari dana individu maupun lembaga ataupun perusahaan yang disebut dalam istilah perbankan adalah dana pihak ketiga. Kegiatan perbankan syariah dalam menghimpun dan memobilisasi dana tabungan masyarkat tentunya memliki tujuan bagi pembangunan ekonomi masyarakat $^{21}$

\section{Pembiayaan.}

Pembiayaan bertujuan untuk profitability, yaitu tujuan untuk meraih hasil dari pembiayaan berupa keuntunngan yang diraih dari bagi hasil yang diperoleh dari usaha yang dikelola bersama nasabah. Oleh karena itu, bank hanya menyalurkan pembiayaan kepada usaha usaha nasabah yang diyakini mampu dan mau mengembalikan pembiayaan yang telah diterimanya. Pembiayaan juga berfungsi untuk meningkatkan utility (daya guna) dari modal/uang. Para penabung menyimpan uangnya di lembaga keuangan. Uang tersebut dalam persentase tertentu ditingkatkan kegunaanya oleh lembaga keuangan. Para pengusaha menikmati pembiayaan dari bank untuk memperluas usahanya. Baik untuk meningkatkan produksi, perdagangan, untuk usaha usaha rehabilitasi, ataupun 
usaha meningkatkan produktifitas secara menyeluruh, pembiayaan menimbulkan gairah usaha masyarakat. pembiayaan sebagai jembatan untuk peningkatan pendapatan nasional. $^{22}$

\section{Bancassurance}

Bancasurrance adalah layanan Bank dalam menyediakan produk asuransi yang memberi perlindungan dan produk investasi untuk memenuhi kebutuhan finansial jangka panjang nasabah. Namun demikian, selain memberikan keuntungan nasabah atau calon nasabah harus memahami risiko yang melekat pada produk tersebut karena meskipun ditawarkan oleh bank, namun tidak dijamin oleh bank. ${ }^{23}$ Bancassurance merupakan aktivitas pemasaran produk asuransi oleh bank yang didasari kerjasama antara bank dan perusahaan asuransi . pelayanannya bertujuan memenuhi kebutuhan nasabah dan memberikan solusi menyeluruh berupa proteksi terhadap resiko. Selain itu, bank dapat meningkatkan fee based income, efektivitas penjualan dan loyalitas nasabah.

\section{Penelitian Terdahulu}

Berikut ini beberapa penelitian terdahulu terkait dengan analisis kinerja keuangan bank, antara lain:

Penelitian Patrick Imam dan Kangni Kpodar yang berjudul Islamic Banking: Good For Growth?. Dalam penelitian ini bahwa kehadiran bank Islam dapat berpengaruh positif pada pertumbuhan perekonomian dan kesejahteraan masyarakat. Penelitiannya menggunakan alat ukur PDB sebagai variabel dependen dan rasio kredit, aset, deposit (DPK) sebagai variabel independen, hasilnya menunjukkan bahwa kredit (pembiayaan), aset dan deposit memiliki hubungan terhadap peningkatan kesejahteraan. Walaupun efek perbankan Islam pada pertumbuhan ekonomi masih relatif belum dominan. ${ }^{24}$

Penelitian Salina Kassim dengan judul Islamic Finance And Economic Growth: The Malaysian Experience pada tahun 2015 dengan variabel terikat indek produksi industri dan variabel bebasnya deposito bank, pembiayaan bank, pembentukan modal, pengeluaran pemerintah dan inflasi. Hasilnya menunjukkan bahwa terdapat pengaruh deposito, pembiayaan dari industri keuangan Islam dan variabel lainnya terhadap pertumbuhan dan memberikan kontribusi penting bagi ekonomi riil dan secara efektif menjalankan peran intermediasi keuangan Islam. ${ }^{25}$ 
Penelitian Hind Lebdaoui dan Joerg Wild dengan judul Islamic Banking Presence And Economic Growth In Southeast Asia. Hasilnya menunjukkan bahwa bank Islam berpengaruh pada pertumbuhan ekonomi dalam jangka panjang terutama di wilayah dengan penduduk mayoritas muslim. Penelitian ini menggunakan variabel dependen PDB riil perkapita dan variabel independen rasio aset dan rasio deposito dan menggunakan beberapa variabel kontrol. ${ }^{26}$

\section{Kerangka Berfikir}

Kerangka teoritis adalah kerangka penalaran yang terdiri dari konsepkonsep atau teori yang menjadi acuan penelitian. Biasanya kerangka teori disusun dalam bentuk matriks, bagan, atau gambar sederhana. Penelitian ini akan menguji variabel dana pihak ketiga, pembiayaan dan bancassurance mempengaruhi langsung terhadap kesejahteraan masyarakat. Kemudian dana pihak ketiga, pembiayaan dan bancassurance mempengaruhi secara tidak langsung namun dengan variabel intervening, yaitu laba bank syariah terhadap kesejahteraan masyarakat. Kerangkanya dapat dilihat dari gambar berikut:

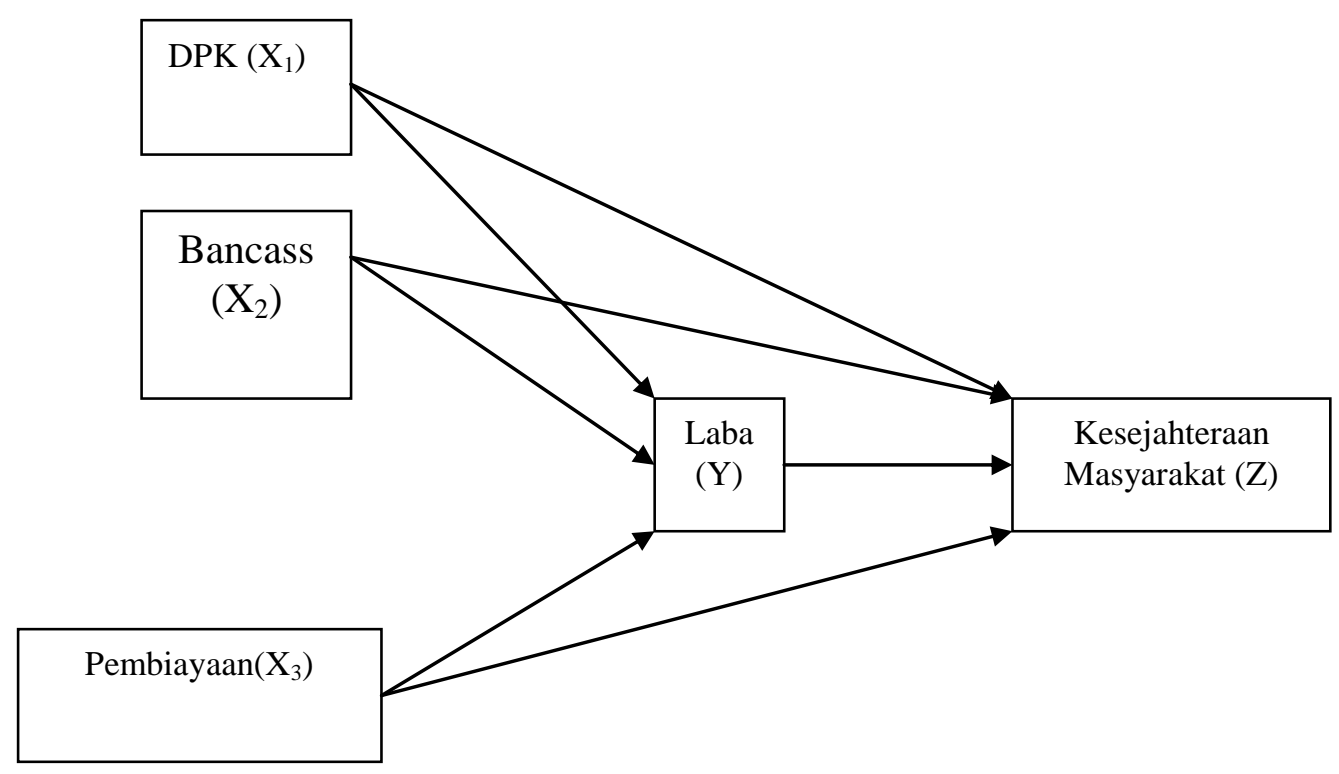

Gambar 1 Kerangka Teoritis 


\section{Metode Penelitian}

Penelitian ini merupakan jenis penelitian kuantitatif. Penelitian deskriptif dalam penelitian ini dimaksudkan untuk menganalisis pengaruh DPK, pembiayaan dan bancassurance terhadap laba dan dampaknya bagi kesejahteraan masyarakat, baik pengaruh langsung maupun pengaruh tidak langsung melalui variabel intervening. Jenis data dalam penelitian ini adalah data kuantitatif. Sedangkan sumber data yang digunakan adalah data sekunder berupa laporan keuangan bulanan bank syariah periode 2014-2018.

Metode analisis data dalam penelitian ini yaitu dengan menggunakan analisis jalur atau metode path analysis dengan menggunakan sistem LISREL. Analisis jalur adalah analisis yang digunakan untuk mengetahui pengaruh langsung dan tidak langsung antara variabel eksogen terhadap variabel endogen. Pertimbangan menggunakan analisis ini karena antara satu variabel dengan variabel lainya mempunyai hubungan karena faktor-faktor yang dianalisis dalam penelitian ini dapat diukur secara langsung. ${ }^{27}$ Analisis jalur diawali dengan menggambarkan secara diagramatik struktur hubungan antar variabel penyebab dengan variabel akibat. Diagram ini disebut diagram jalur (path diagram) yang bentuknya ditentukan oleh proposisi teoritik yang berasal dari kerangka pikir tertentu. Diagram jalur merupakan gambar yang menyatakan struktur hubungan antara variabel bebas dengan variabel terikat

\section{Hasil Penelitian dan Pembahasan}

\section{Normalitas Data}

Uji normalitas digunakan untuk mendeteksi kenormalan sebaran data dari penelitian, apakah berdistribusi normal atau tidak. Normalitas data dapat dilihat dari hasil output lisrel yaitu dari nilai P-value pada Skewnes dan Kurtosis. Data dikatakan berdistribusi normal jika nilai P-value pada Skewnes dan Kurtosis di setiap variable penelitian lebih besar dari 0,05. Berikut hasil output lisrel untuk pengujian normalitas data:

Tabel 1 Test of Univariate Normality for Continuous Variables

\begin{tabular}{|c|c|c|c|c|c|c|}
\hline \multirow{2}{*}{ Variabel } & \multicolumn{2}{|c|}{ Skewness } & \multicolumn{2}{c|}{ Kurtosis } & \multicolumn{2}{c|}{ Skewness and Kurtosis } \\
\cline { 2 - 7 } & Z-Score & P-value & Z-Score & P-value & Chi-Square & P-value \\
\hline X1 & 0.037 & 0.971 & 0.077 & 0.939 & 0.007 & 0.996
\end{tabular}




\begin{tabular}{|c|c|c|c|c|c|c|}
$\mathrm{X} 2$ & 0.587 & 0.557 & -1.035 & 0.301 & 1.416 & 0.493 \\
$\mathrm{X} 3$ & 0.000 & 1.000 & 0.135 & 0.893 & 0.018 & 0.991 \\
$\mathrm{Y}$ & -0.010 & 0.992 & 0.121 & 0.904 & 0.015 & 0.993 \\
$\mathrm{Z}$ & -0.011 & 0.991 & -0.100 & 0.920 & 0.010 & 0.995 \\
\hline
\end{tabular}

Dari hasil tersebut dapat kita lihat bahwa data untuk variable X1, X2, X3, $\mathrm{Y}$ dan $\mathrm{Z}$ berdistribusi normal. Hal ini ditandai dengan nilai $\mathrm{P}$-value X1 pada skewness dan kurtosis sebesar 0.996 lebih besar dari 0,05. P-value X2 pada skewness dan kurtosis sebesar 0.493 lebih besar dari 0,05. P-value X3 pada skewness dan kurtosis sebesar 0.991 lebih besar dari 0,05. P-value Y pada skewness dan kurtosis sebesar 0.993 lebih besar dari 0,05. P-value Z pada skewness dan kurtosis sebesar 0.995 lebih besar dari 0,05 Selain dari nilai P-value pada skewness dan kurtosis Lisrel juga menampilkan dalam bentuk histogram untuk data yang berdistribusi normal sebagai berikut:

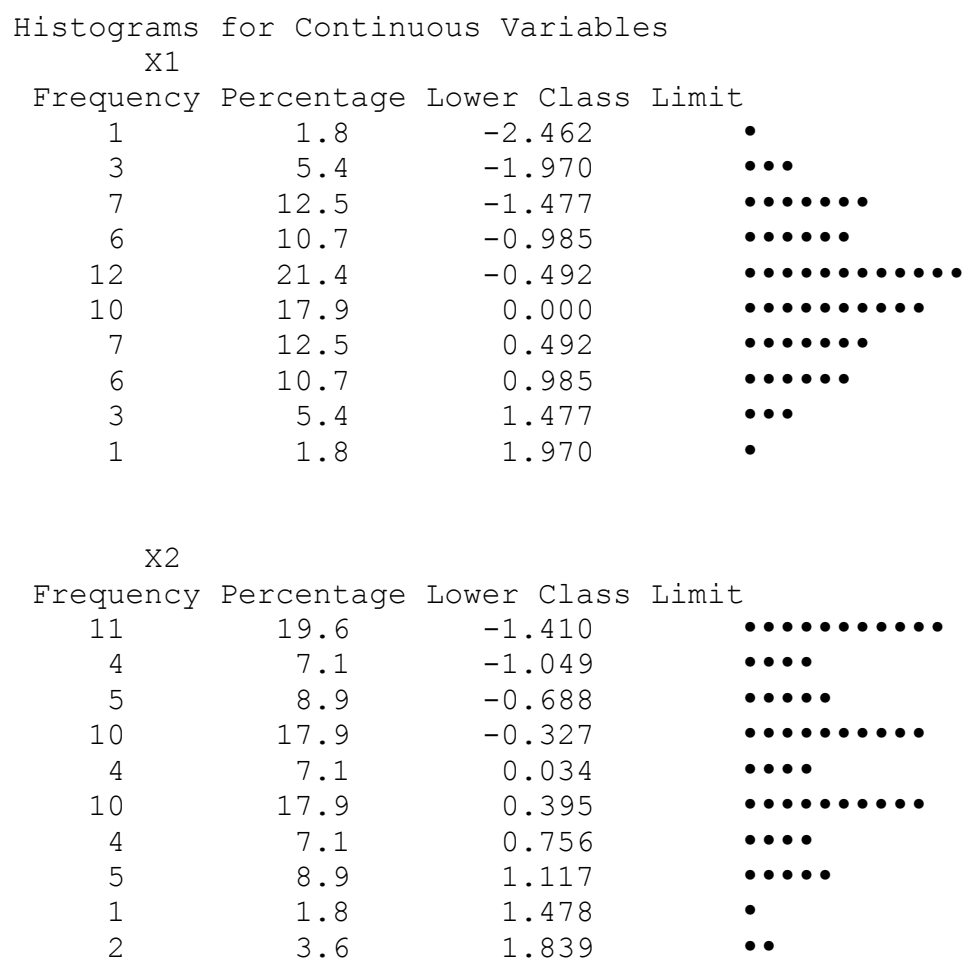

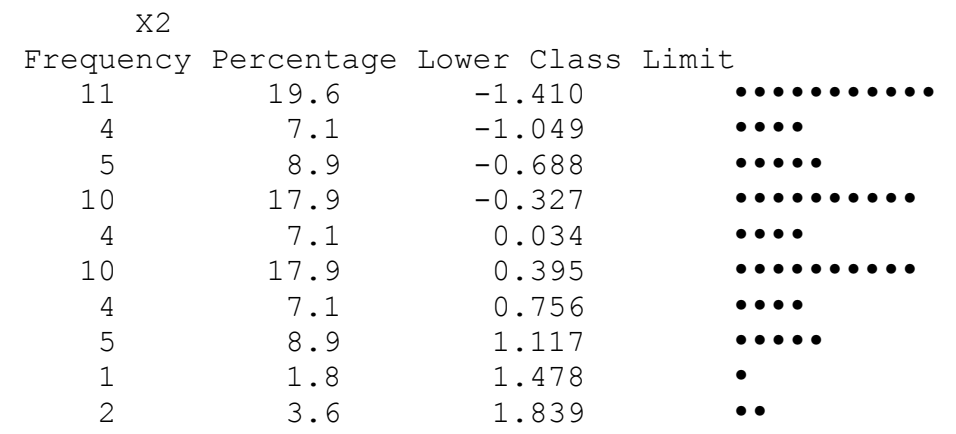


Dian Adila Putra: Analisis Pengaruh Dana Pihak Ketiga, Pembiayaan, |31

\begin{tabular}{|c|c|c|c|c|}
\hline & & & & \\
\hline 5 & 8.9 & 0.985 & & $\square \square \square \square$ \\
\hline 3 & 5.4 & 1.477 & & $\square \square$ \\
\hline 1 & 1.8 & 1.970 & & $\square$ \\
\hline \multicolumn{5}{|l|}{$\mathrm{Y}$} \\
\hline Frequency & Percentage & Lower Class & Limit & \\
\hline 1 & 1.8 & -2.462 & & $\square$ \\
\hline 3 & 5.4 & -1.970 & & $\square \square$ \\
\hline 5 & 8.9 & -1.477 & & $\square \square \square \square$ \\
\hline 8 & 14.3 & -0.985 & & 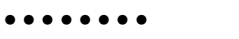 \\
\hline 11 & 19.6 & -0.492 & & पमामामाप \\
\hline 11 & 19.6 & 0.000 & & पमणमामा \\
\hline 8 & 14.3 & 0.492 & & पमापमा \\
\hline 5 & 8.9 & 0.985 & & $\square \square \square \square$ \\
\hline 3 & 5.4 & 1.477 & & $\square \square$ \\
\hline 1 & 1.8 & 1.970 & & $\square$ \\
\hline \multicolumn{5}{|l|}{ Z } \\
\hline Frequency & Percentage & Lower Class & Limit & \\
\hline 2 & 3.6 & -2.200 & & $\square$ \\
\hline 3 & 5.4 & -1.760 & & $\square \square$ \\
\hline 6 & 10.7 & $-1 \cdot 320$ & & $\square \square \square \square$ \\
\hline 6 & 10.7 & -0.880 & & पमणम \\
\hline 12 & 21.4 & -0.440 & & 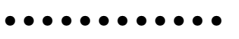 \\
\hline 9 & 16.1 & 0.000 & & पमणमाप \\
\hline 9 & 16.1 & 0.440 & & $\square \square \square म \square \square \square$ \\
\hline 3 & 5.4 & 0.880 & & $\square$ \\
\hline 4 & 7.1 & 1.320 & & $\square \square \square$ \\
\hline 2 & 3.6 & 1.760 & & $\square \square$ \\
\hline
\end{tabular}

\section{Analisa Pengaruh Langsung Pada Sub Struktural Model Pertama}

Berikut persamaan struktural yang pertama:

$$
\begin{aligned}
& \mathrm{Y}=-0.25 * \mathrm{X} 1+0.62 * \mathrm{X} 2+0.15 * \mathrm{X} 3, \text { Errorvar. }=0.80, \mathrm{R}^{2}=0.21 \\
& \begin{array}{llll}
(0.22) & (0.22) \quad(0.13) & (0.16)
\end{array} \\
& \begin{array}{llll}
-1.15 & 2.84 & 1.18 & 5.10
\end{array}
\end{aligned}
$$

Hasil tersebut memperlihatkan bahwa ketiga variable (X1,X2 dan X3) yaitu DPK, Pembiayaan dan Bancassurance secara simultan atau bersama sama mempengaruhi variabel $\mathrm{Y}$ atau Laba sebesar $21 \%$ hal ini dilihat dari nilai $\mathrm{R}^{2}$ sebesar 0,21. Hal ini dapat di simpulkan bank syariah bukan hanya profit oriented namun ditambah falah. Namun secara parsial tidak semua variable eksogen mempengaruhi Y dalam hal ini laba. Persamaan struktural tersebut menunjukkan variable X1 (DPK) tidak berpengaruh terhadap variabel Y (laba) dengan nilai koefisien -0,25. Nilai koefisien DPK negatif dikarenakan DPK dengan cost of fund yang timbul akibat dari penghimpunan dana dapat menguras laba terutama jika komposisi DPK didominasi deposito ketimbang tabungan dan giro. Standard error sebesar 0,22. Pengaruh tersebut tidak signifikan, hal ini bisa dilihat dari nilai t-hitung sebesar -1,15, nilai ini lebih besar dari nilai t-tabel yakni -1,67 (-t-hitung> - t-tabel yaitu -1,15> -1,67). Sedangkan variable X2 (Pembiayaan) berpengaruh 
signifikan terhadap variable Y (laba) dengan nilai koefisien 0,62. Artinya laba bank syariah dipengaruhi oleh pembiyaan sebesar 62\% sisanya sebesar $38 \%$ dipengaruhi variabel lain. Standard error sebesar 0,22. Pengaruh tersebut sangat signifikan, hal ini bisa dilihat dari nilai t-hitung sebesar 2,84, nilai ini lebih besar dari nilai t-tabel yakni 1,67 (t-hitung > t-tabel yaitu 2,84>1,67). Kemudian variabel X3 (Bancassurance) tidak berpengaruh terhadap variabel Y (laba) dengan nilai koefisien 0,15 . artinya hanya $15 \%$ saja pendapatan bancassurance mempengaruhi laba bank syariah. standard error sebesar 0,13 . Hal ini bisa dilihat dari nilai t-hitung sebesar 1,18, nilai ini lebih kecil dari nilai t-tabel yakni 1,67 (thitung < t-tabel yaitu $1,18<1,67)$. dan rangkuman hasil sub struktul model pertama dapat dilihat sebagaimana ilustrasi berikut:

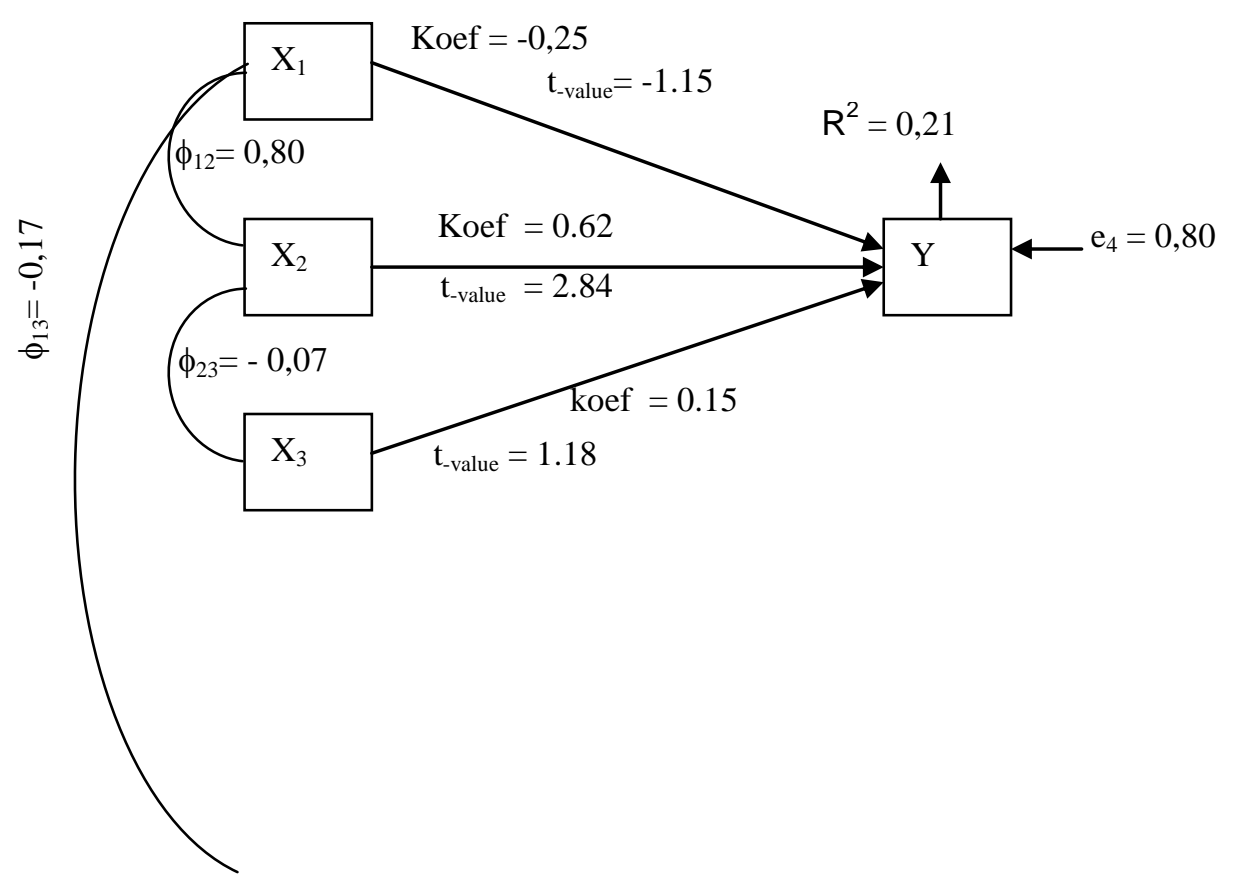

Gambar 2 Sub Struktur Model Pertama

\section{Analisa Pengaruh Langsung Pada Sub Struktural Model Kedua}

Berikut persamaan struktural yang kedua:

$$
\begin{array}{ccccc}
\mathrm{Z}=0.28 * \mathrm{Y}+0.65 * \mathrm{X} 1 & -0.083 * \mathrm{X} 2 & -0.44 * \mathrm{X} 3, \text { Errorvar. }=0.26, \mathrm{R}^{2}=0.74 \\
(0.079) & (0.13) & (0.13) & (0.073) & (0.051) \\
3.58 & 5.17 & -0.62 & -6.07 & 5.10
\end{array}
$$

Hasil tersebut memperlihatkan bahwa ketiga variabel (X1, X2 dan X3) yaitu DPK, pembiayaan dan bancassurance dan variabel intervening laba (Y) 
secara simultan atau bersama sama mempengaruhi kesejahteraan masyarakat (variabel Z) sebesar 74\%. Persentase ini dilihat dari nilai $\mathrm{R}^{2}$ sebesar 0,74. Artinya keberadaan bank syariah dengan kegiatan usahanya baik menghimpun dana, menyalurkan pembiyaan maupun jasa bancassurance berpengaruh pada kesejahteraan masyarakat Indonesia. Namun secara parsial tidak semua variable eksogen mempengaruhi variabel endogen ( $Z$ ) dalam hal ini kesejahteraan masyarakat. Persamaan struktural di atas menunjukkan bahwa laba (variabel Y) berpengaruh signifikan terhadap kesejahteraan masyarakat (variabel Z) dengan nilai koefisien 0,28. Artinya jika bank syariah memperoleh laba maka akan berpengaruh sebesar $28 \%$ terhadap kesejahteraan, dengan memperoleh laba bank syariah bisa ekspansi lebih luas dan memberi dampak pada masyarakat. Standard error sebesar 0,079. Pengaruh tersebut sangat signifikan, hal ini bisa dilihat dari nilai t-hitung sebesar 3,58 nilai ini lebih besar dari nilai t-tabel yakni 1,67 (thitung > t-tabel yaitu 3,58>1,67).

Lalu variabel X1 pada persamaan struktural kedua, DPK berpengaruh terhadap kesejahteraan masyarakat (variabel Z) dengan nilai koefisien 0,65. Sebanyak 65\% DPK mempengaruhi kesejahteraan masyarakat. Artinya semakin banyak dana pihak ketiga maka berindikasi meningkatnya kesejahteraan masyarakat karena masyarakat mampu menyisihkan penghasilannya untuk simpanan baik di tabungan maupun deposito. Dan tentunya bagi hasil yang dihasilkan dari simpanan akan meningkatkan pendapatan masyarakat. Standard error sebesar 0,13. Pengaruh tersebut signifikan, hal ini bisa dilihat dari nilai thitung sebesar 5,17, nilai ini lebih besar dari nilai t-tabel yakni 1,67 (t-hitung > ttabel yaitu $5,17>1,67)$.

Sedangkan variabel X2 (pembiayaan) tidak berpengaruh terhadap kesejahteraan masyarakat (variabel Z) dengan nilai koefisien -0,083. Artinya pembiayaan merupakan beban hutang bagi masyarakat yang tentunya akan mengurangi penghasilannya walaupun di saat yang sama dapat meningkatkan penjualan karena bertambah modal atau dapat di indikasi pembiayaan bank syariah di Indonesia didominasi pembiayaan konsumtif yang hanya bisa menambah beban pada penghasilan masyarakat. Standard error sebesar 0,13. Tidak terdapat pengaruh, hal ini bisa dilihat dari nilai t-hitung sebesar -0,62, nilai ini lebih besar dari nilai t-tabel yakni -1,67 (-t-hitung > - t-tabel yaitu -0,62 > $1,67)$. 
Kemudian variabel X3 (bancassurance) berpengaruh negatif terhadap kesejahteraan masyarakat (variabel Z) dengan nilai koefisien -0,44. Artinya sebesar $44 \%$ pembayaran premi bancassurance akan mengurangi pendapatan masyarakat walaupun di saat yang sama tingkat kenyamanan bertambah apabila terjadi resiko pada seseorang baik itu terkait kesehatan maupun kematian. Standard error sebesar 0,073. Bancassurance memiliki pengaruh negatif, hal ini bisa dilihat dari nilai t-hitung sebesar -6,07, nilai ini lebih kecil dari nilai t-tabel yakni -1,67 (-t-hitung < -t-tabel yaitu -6,07<-1,67). dan rangkuman hasil sub struktul model kedua dapat dilihat sebagaimana ilustrasi berikut:

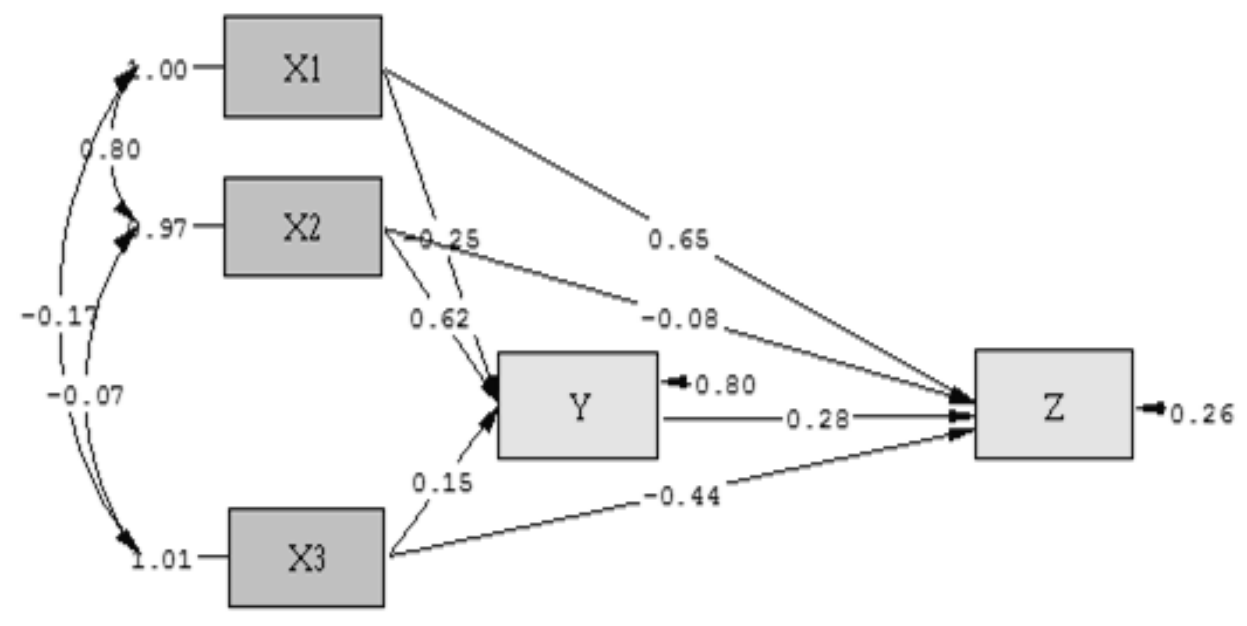

Chi-Square $=0.00, d f=0, p-v a l u e=1.00000$, RMSEA $=0.000$

Gambar 3 Standardizerd Solution Struktual Model Kedua

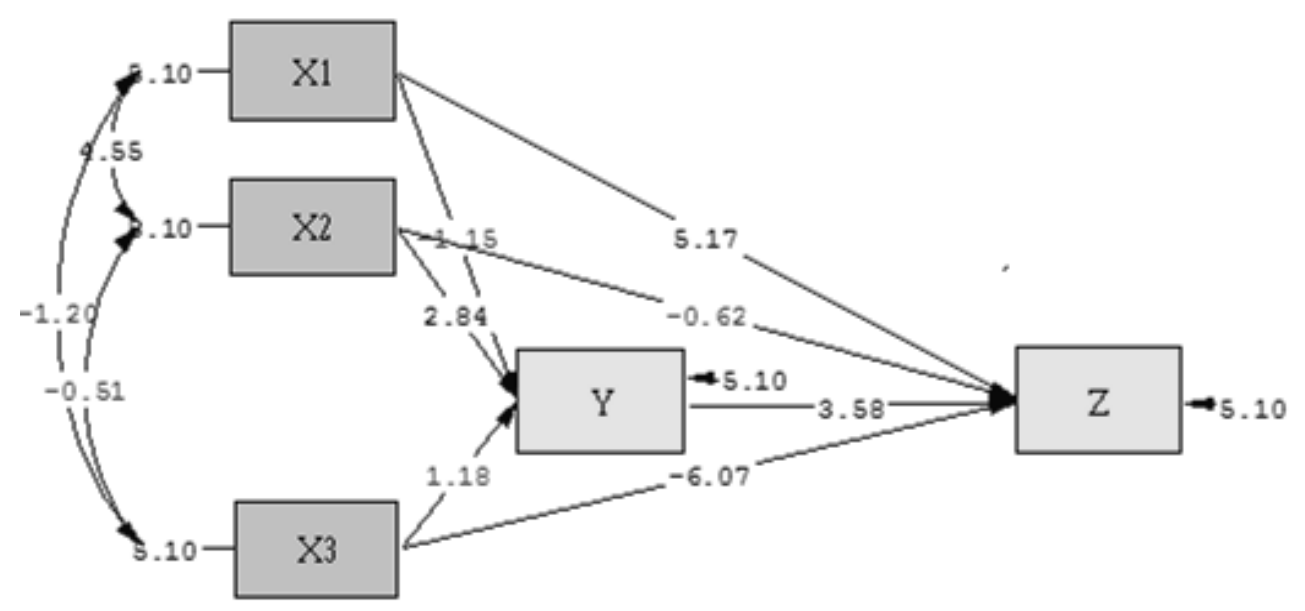

Chi-Square $=0.00, d f=0, p-$ value $=1.00000, \mathrm{RMSEA}=0.000$ 
Dian Adila Putra: Analisis Pengaruh Dana Pihak Ketiga, Pembiayaan, |35

\section{Gambar 4 T-Value Struktural Model Kedua}

Dari hasil output Lisrel path diagram nilai koefisien setiap variabel dapat dilihat dari path diagram standardizerd solutions. Sedangkan signifikansi pengaruh antar variabel eksogen dengan variabel endogen dapat dilihat dari path diagram t-value. Nilai t-value berwarna merah menunjukkan bahwa tidak ada pengaruh antar variabel.

\section{Analisa Pengaruh Tidak Langsung (Indirect Effect) Dan Pengaruh Total (Total Effect)}

Berikut hasil output Lisrel untuk total effect dan indirect effect:

$$
\begin{aligned}
& \text { Total Effects of } X \text { on } Y \\
& \begin{array}{rrrr} 
& X 1 & X 2 & X 3 \\
Y & ------ & ------ & ----- \\
& -0.25 & 0.62 & 0.15 \\
& (0.22) & (0.22) & (0.13) \\
& -1.15 & 2.84 & 1.18 \\
\mathrm{Z} & & & \\
& 0.58 & 0.09 & -0.40 \\
& (0.14) & (0.14) & (0.08) \\
& 4.18 & 0.67 & -4.99
\end{array} \\
& \text { Indirect Effects of } \mathrm{X} \text { on } \mathrm{Y} \\
& \begin{array}{rrrr} 
& X 1 & X 2 & X 3 \\
& ------ & ---- & ---- \\
& -- & -- & - \\
Z & & & 0.04 \\
& -0.07 & 0.18 & 0.04) \\
& (0.06) & (0.08) & (0.04) \\
& -1.10 & 2.23 & 1.12
\end{array} \\
& \text { Total Effects of } Y \text { on } Y
\end{aligned}
$$

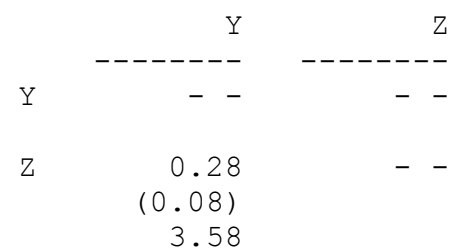

Hasil output Lisrel di atas dapat kita simpulkan sebagai berikut:

Tabel 2 Simpulan Hasil Output Lisrel

\begin{tabular}{|l|r|c|r|}
\hline \multicolumn{1}{|c|}{ Hubungan Sruktural } & $\begin{array}{c}\text { Pengaruh } \\
\text { Langsung }\end{array}$ & \multicolumn{1}{c|}{$\begin{array}{c}\text { Pengaruh Tidak } \\
\text { Langsung }\end{array}$} & \multicolumn{1}{c|}{$\begin{array}{c}\text { Total } \\
\text { Pengaruh }\end{array}$} \\
\hline DPK ------> Laba & $(0.25)$ & - & $(0.25)$ \\
\hline DPK -----> Kesejahteraan Masyarakat & 0.65 & $(-025 * 0.28)=-0.07$ & 0.58 \\
\hline Pembiayaan -----> Laba & 0.62 & - & 0.62 \\
\hline Pembiayaan -----> Kesejahteraan & $(0.08)$ & $(0.62 * 0.28)=0.173$ & 0.09 \\
\hline
\end{tabular}




\begin{tabular}{|l|r|c|r|} 
Masyarakat & & & \\
\hline Bancaassurance -----> Laba & 0.15 & - & 0.15 \\
\hline $\begin{array}{l}\text { Bancaassurance -----> Kesejahteraan } \\
\text { Masyarakat }\end{array}$ & $(0.44)$ & $(0.15 * 028)=0.042$ & $(0.40)$ \\
\hline Laba ----> Kesejahteraan Masyarakat & 0.28 & - & 0.28 \\
\hline
\end{tabular}

Jika merujuk pada gambar sebelumnya, terdapat sebanyak 3 (tiga) jalur pengaruh tidak langsung variabel DPK, pembiayaan dan bancassurance melalui variabel laba ke variabel kesejahteraan masyarakat. Ketiga jalur pengaruh tidak langsung tersebut dapat dianalisis berdasarkan perhitungan sebagai berikut:

a. Perkalian antara parameter jalur yang menghubungkan variabel Dana Pihak Ketiga ke variabel laba dengan parameter jalur yang menghubungkan variabel laba dengan variabel kesejahteraan masyarakat. Berdasarkan ketentuan tersebut, maka diperoleh nilai koefisien pengaruh tidak langsung dana pihak ketiga terhadap kesejahteraa masyarakat melalui laba sebesar - 0,07 dengan nilai koefisien $t_{\text {hitung }}$ yang diperoleh sebesar -1,10. Berdasarkan hasil analisis nilai koefisien $t_{\text {hitung }}$ tersebut dan nilai $t_{\text {tabel }}=-1,67$. nilai $-t_{\text {hitung }}>-t_{\text {tabel }}(-1,10>$ -1,67) maka dapat dikatakan bahwa pengaruh tidak langsung dana pihak ketiga terhadap kesejahteraan masyarakat melalui laba dinyatakan tidak berpengaruh.

b. Perkalian antara parameter jalur yang menghubungkan variabel Pembiayaan ke variabel laba dengan parameter jalur yang menghubungkan variabel laba dengan variabel kesejahteraan masyarakat. Berdasarkan ketentuan tersebut, maka diperoleh nilai koefisien pengaruh tidak langsung pembiayaan terhadap kesejahteraa masyarakat melalui laba sebesar 0,173 dengan nilai koefisien $t_{\text {hitung }}$ yang diperoleh sebesar 2,23. Berdasarkan hasil analisis nilai koefisien $t_{\text {hitung }}$ tersebut dan nilai $t_{\text {tabel }}=1,67$. nilai $t_{\text {hitung }}>t_{\text {tabel }}(2,23>1,67)$ maka dapat dikatakan bahwa pengaruh tidak langsung Pembiayaan terhadap kesejahteraan masyarakat melalui laba dinyatakan sangat signifikan.

c. Perkalian antara parameter jalur yang menghubungkan variabel bancassurance ke variabel laba dengan parameter jalur yang menghubungkan variabel laba dengan variabel kesejahteraan masyarakat. Berdasarkan ketentuan tersebut, maka diperoleh nilai koefisien pengaruh tidak langsung bancassurance terhadap kesejahteraa masyarakat melalui laba sebesar 0,042 dengan nilai koefisien $t_{\text {hitung }}$ yang diperoleh sebesar 1,12. Berdasarkan hasil 
analisis nilai koefisien $t_{\text {hitung }}$ tersebut dan nilai $t_{\text {tabel }}=1,67$. nilai $t_{\text {hitung }}<t_{\text {tabel }}$ $(1,12<1,67)$ maka dapat dikatakan bahwa pengaruh tidak langsung bancassurance terhadap kesejahteraan masyarakat melalui laba dinyatakan tidak berpengaruh signifikan.

d. Pengaruh total variabel dana pihak ketiga $\left(\mathrm{X}_{1}\right)$ terhadap kesejahteraan masyarakat (Z) dihitung berdasarkan penjumlahan paramter pengaruh langsung variabel dana pihak ketiga $\left(\mathrm{X}_{1}\right)$ terhadap kesejahteraan masyarakat (Z) dengan jumlah seluruh parameter pengaruh tidak langsung variabel dana pihak ketiga $\left(\mathrm{X}_{1}\right)$ terhadap kesejahteraan masyarakat $(\mathrm{Z})$. Berdasarkan pemahaman tersebut, maka koefisien pengaruh total variabel dana pihak ketiga $\left(\mathrm{X}_{1}\right)$ terhadap kesejahteraan masyarakat $(\mathrm{Z})$ sebesar 0,58 , dengan nilai koefisien $t_{\text {hitung }}$ sebesar 4.18. Oleh karena nilai koefisien $t_{\text {tabel }}=1,67$ lebih

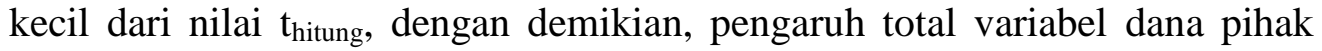
ketiga $\left(\mathrm{X}_{1}\right)$ terhadap kesejahteraan masyarakat $(\mathrm{Z})$ dinyatakan sangat signifikan

e. Pengaruh total variabel pembiayaan $\left(X_{2}\right)$ terhadap kesejahteraan masyarakat (Z) dihitung berdasarkan penjumlahan parameter pengaruh langsung variabel pembiayaan $\left(\mathrm{X}_{2}\right)$ terhadap kesejahteraan masyarakat $(\mathrm{Z})$ dengan jumlah seluruh parameter pengaruh tidak langsung variabel pembiayaan $\left(\mathrm{X}_{2}\right)$ terhadap kesejahteraan masyarakat (Z). Berdasarkan pemahaman tersebut, maka koefisien pengaruh total variabel pembiayaan $\left(\mathrm{X}_{2}\right)$ terhadap kesejahteraan masyarakat $(\mathrm{Z})$ sebesar 0,09 , dengan nilai koefisien $t_{\text {hitung }}$ sebesar 0,67 . Oleh karena nilai koefisien $t_{\text {tabel }}=1,67$ lebih besar dari nilai $t_{\text {hitung }}$, dengan demikian, pengaruh total variabel pembiayaan $\left(X_{2}\right)$ terhadap kesejahteraan masyarakat $(\mathrm{Z})$ dinyatakan tidak signifikan.

f. Pengaruh total variabel bancassurance $\left(\mathrm{X}_{3}\right)$ terhadap kesejahteraan masyarakat (Z) dihitung berdasarkan penjumlahan paramter pengaruh langsung variabelbancassurance $\left(\mathrm{X}_{3}\right)$ terhadap kesejahteraan masyarakat $(\mathrm{Z})$ dengan jumlah seluruh parameter pengaruh tidak langsung variabel bancassurance $\left(\mathrm{X}_{3}\right)$ terhadap kesejahteraan masyarakat $(\mathrm{Z})$. Berdasarkan pemahaman tersebut, maka koefisien pengaruh total variabel bancassurance $\left(\mathrm{X}_{3}\right)$ terhadap kesejahteraan masyarakat $(\mathrm{Z})$ sebesar -0,40, dengan nilai koefisien $t_{\text {hitung }}$ sebesar $-4,99$. Oleh karena nilai koefisien $t_{\text {tabel }}=-1,67$ lebih besar dari nilai $t_{\text {hitung, dengan demikian, pengaruh total variabel }}$ 
bancassurance $\left(\mathrm{X}_{3}\right)$ terhadap kesejahteraan masyarakat $(\mathrm{Z})$ dinyatakan signifikan berpengaruh negatif.

\section{Goodness of Fit Statistics}

Goodness of fit statistics digunakan untuk menentukan apakah model yang kita buat sudah fit atau belum, evaluasinya dengan melihat nilai yang dihasilkan pada Goodness of fit statistics yaitu dengan melihat angka dari Chi-square, jika nilainya mendekati 0 maka model sempurna dan fit. Begitu juga dilihat dari nilai P-value harus lebih besar > 0.05, sempurna jika nilainya mendekati atau sama dengan 1. Berikut hasil output lisrel untuk Goodness of fit statistics:

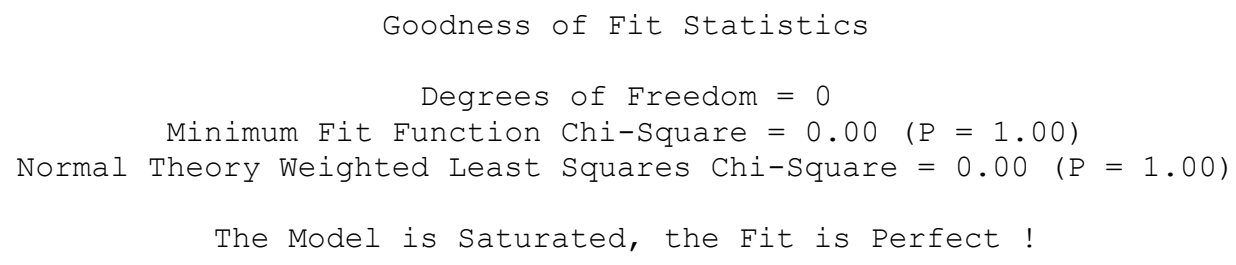

Hasil ini memberikan arti bahwa model memiliki fit yang sangat baik karena memiliki nilai Chi-square $=0.00$ dan nilai $\mathrm{P}=1(\mathrm{P}>0.05)$. dengan nilai Chi-square sebesar 0 menunjukkan bahwa model memiliki fit yang sempurna (fit is perfect).

\section{Kesimpulan}

Sebagaimana yang telah dipaparkan pada hasil penelitian dan pembahasan sebelumnya, maka dapat dibuat kesimpulan sebagai berikut:

a. Dana pihak ketiga tidak berpengaruh langsung terhadap laba bank syariah. nilai koefisien DPK negatif $(-0,25)$ dikarenakan DPK dengan cost of fund (COF) yang timbul akibat dari penghimpunan dana dapat menguras laba terutama jika komposisi DPK didominasi deposito ketimbang tabungan dan giro. Namun karena Ho diterima bermakna komposisi DPK tidak sepenuhnya terkonsentrasi pada deposito yang memiliki COF tinggi ketimbang giro dan tabungan.

b. Dana pihak ketiga sangat signifikan berpengaruh langsung terhadap kesejahteraan masyarakatsebesar 65\%. Artinya semakin banyak dana simpanan masyarakat dalam bentuk tabungan maupun deposito menunjukkan 
kemampuan masyarakat dalam menyisihkan sebagian pendapatannya setelah digunakan untuk konsumsi buat menabung dan masyarakat dapat tambahan penghasilan dari bagi hasil dari tabungan maupun deposito.

c. Pembiayaan sangat signifikan berpengaruh langsung terhadap laba bank syariahsebesar $62 \%$. Artinya semakin banyak pembiayaan yang disalurkan ke masyarakat baik dalam bentuk dalam bentuk pembiayaan konsumtif maupun produktif akan menumbuhkan laba pada bank syariah.

d. Pembiayaan tidak berpengaruh langsung terhadap kesejahteraan masyarakat. Koefisien bernilai negatif $(-0,083)$ Artinya terdapat indikasi bahwa dominasi pembiyaan hanya pada sektor pembiayaan konsumtif jadi kewajiban pembayaran atas pembiayaan hanya menjadi pengurang bagi penghasilan masyarakat dan disimpulkan tidak produktif.

e. Bancassurance tidak berpengaruh langsung terhadap laba bank syariah. Jadi bank syariah setidaknya tidak lagi menjadikan produk bancassurance sebagai penopang untuk menghasilkan laba.

f. Bancassurance memberikan pengaruh langsung yang signifikan terhadap kesejahteraan masyarakat (-0.04). Nilai koefisien negatif artinya bancassurance memberikan pengaruh yang negatif bagi kesejahteraan masyarakat karena posisi premi bancassurance dapat mengurangi pendapatan masyarakat.

g. Laba sangat signifikan mempengaruhi secara langsung terhadap kesejahteraan masyarakat sebesar 28\%. Artinya jika bank syariah memperoleh posisi laba pada usahanya akan berdampak positif pada kesejahteraan masyarakat.

h. Dana pihak ketiga tidak berpengaruh secara tidak langsung terhadap kesejahteraan masyarakat melalui laba bank syariah.

i. Pembiayaan sangat signifikan berpengaruh secara tidak langsung terhadap kesejahteraan masyarakat melalui laba bank syariahsebesar 18\%. Hal ini memiliki makna bahwa jika bank syariah memperoleh laba berarti pembiayaan yang disalurkan dapat tertagih dan memiliki kualitas lancar sehingga mendongkrak laba dan tentunya nasabah pembiayaan dapat dipastikan berkembang usahanya karna mampu membayar kewajiban terhadap bank syariah tepat waktu. 
j. Bancassurance tidak berpengaruh secara tidak langsung terhadap kesejahteraan masyarakat melalui laba bank syariah. Maka bagi bank syariah dapat mengambil kebijakan untuk tidak bertumpuh pada penjualan asuransi yang ada pada produk bancassurance.

Berdasarkan kesimpulan di atas, maka saran-saran yang dapat diberikan adalah bagi bank syariah di Indonesia, dengan penelitian ini menjadi bahan evaluasi bank syariah untuk merumuskan target kegiatan usaha yang lebih fokus pada pembiayaan dengan konsep prudensial banking dan menghimpun dana pihak ketiga dengan program yang merujuk pada low cost of fund. Karena kedua kegiatan ini yang memberi dampak positif bagi profit perusahaan dan kesejahteraan masyarakat Indonesia. Sedang kegiatan jasa lebih kepada produk pelengkap. Sedangkan bagi peneliti memberikan wawasan dan pemahaman bahwa kembali pada kegiatan usaha bank menurut Undang-Undang No. 21 tahun 2008 merupakan asas bagi bank syariah untuk memberikan kontribusi bagi negara Indonesia. Penelitian ini hanya terfokus pada kegiatan umum usaha bank syariah, dan untuk peneliti selanjutnya, dapat menjadi referensi awal dan bisa meneliti lebih tajam seperti mengklasifikasi jenis pembiayaan yang lebih dominan memberi efek laba maupun kesejahteraan masyarakat dan mengklasifikasi produk penghimpunan dana yang lebih dominan memberikan kontribusi apakah giro, tabungan maupun deposito, serta produk jasa-jasa perbankan syariah lainnya.

\section{Catatan}

${ }^{1}$ Pembukaan UUD 1945, Undang Undang Dasar Republik Indonesia tahun 1945.

${ }^{2}$ Dampriyanto, Undang Undang Dasar Republik Indonesia tahun 1945 (Sidoarjo: Masmedia Buana Pustaka, 2009), h. 31

${ }^{3}$ Ibid, h. 25

${ }^{4}$ Syaikh Syafiyurrahman Al-Mubarakfury, Sirah Nabawiyah, diterjemahkan oleh Zenal Muttaqin, (Bandung: Jabal, 2014) h. 234

${ }^{5}$ Adiwarman A Karim, Bank Islam Analisis fiqih dan Keuangan, ed 3, (Jakarta: PT Raja Gravindo Persada, 2009), h.19

${ }^{6}$ Pusat Pengkajian dan Pembangunan Ekonomi Islam (P3EI), Ekonomi Islam, (Jakarta : PT. Raja Grafindo Persada, 2008), h. 98

${ }^{7}$ Max Weber, The Protestant Ethic and the Spirit of Capitalism, Seperti dikutip oleh Muhammad Syafi'i Antonio, Bank Syariah dari Teori ke Praktek, Cet. 27 (Jakarta: Gema Insani, 2017), h.3

${ }^{8}$ Redaksi Sinar Grafika, Undang-undang PerbankanNo. 10 tahun 1998. cet. 5 (Jakarta: Sinar Grafika, 2005), h. 9

${ }^{9}$ Indonesia Legal Center Publishing, Himpunan Peraturan Perundang Undang Perbankan Syariah UU RI No. 21 Tahun 2008. Cet. 1 (Jakarta: Karya Gemilang, 2009), h.5
} 
${ }^{10}$ Hind Lebdaoui dan Joerg Wild, "Islamic Banking Presence and Economic Growth in Southeast Asia", Emerald:International Journal of Islamic and Middle Eastern Finance and Management, Vol.9, No.4, 2016, pp. 551-569

${ }^{11}$ Veithzal rivai dan Andria Permata Veithzal, Islamic Financial Management, (Jakarta : Raja Grafindo Persada, 2008), h.7

${ }^{12}$ ibid h.7-8 mei 2018

${ }^{13}$ www.bi.go.id/id/iek/produk-jasa-perbankan/jenis/Contents/tab6.aspx di akses tanggal 31

${ }^{14}$ Muhammad Rajab, Manager Marketing Bank Sinarmas Syariah Medan, Wawancara di Medan, Tanggal 12 maret 2018

${ }^{15}$ Sambutan Direktur Pengawas Lembaga Jasa Keuangan OJK Kantor Regional 5 Sumbagut, bapak Mulyanto pada acara pembukaan kantor KCS Medan Bank Sinarmas Syariah tgl 19 januari 2018

${ }^{16}$ Prathama Rahardja dan Mandala Manurung, Pengantar Ilmu Ekonomi Mikro dan Makr..,h.208

${ }^{17}$ Ibid,h.203

${ }^{18}$ Adiwarman Azwar Karim, Bank Islam Analisis Fiqh dan Keuangan,ed3 (Jakarta:PT.Raja Grafindo Persada,2009) h. 18

${ }^{19}$ Prathama Rahardja dan Mandala Manurung, Pengantar Ilmu Ekonomi Mikro dan Makro (Jakarta: Fak. Ekonomi UI, 2004), h. 123.

${ }^{20}$ Sofyan Harahap, Teori Akuntansi (Jakarta: Grafindo Persada, 2002), h. 146

${ }^{21}$ Ibrahim Warde, Islamic Finance keuangan Islam dalam Perekonomian Global, diterjemahkan oleh Andriyadi Ramli, (Yogyakarta: Pustaka Pelajar, 2009), h. 369

${ }^{22}$ Veithzal rivai dan Andria Permata Veithzal, Islamic Financial Management, (Jakarta : Raja Grafindo Persada, 2008), h.48

${ }^{23}$ www.bi.go.id/id/iek/produk-jasa-perbankan/jenis/Contents/tab6.aspx di akses tanggal 31 mei 2018

${ }^{24}$ Patrick Imam dan Kangni Kpodar, "Islamic Banking : Good for growth?", Elsevier:International Journal of Economic Modelling, No.59, 2016, pp. 387-401

${ }^{25}$ Salina Kassim, "Islamic Finance and Economic Growth: the Malaysian Experience", Sciencedirect: Global Finance Jurnal, 2016, h.11-14

${ }^{26}$ Hind Lebdaoui dan Joerg Wild, "Islamic Banking Presence and Economic Growth in Southeast Asia", Emerald:International Journal of Islamic and Middle Eastern Finance and Management, Vol.9, No.4, 2016, pp. 551-569

${ }^{27}$ Riduwan dan Engkos Achmad Kuncoro. Analisis Jalur : Path Analysis, Edisi 2, (Bandung: Alfabeta, 2008) h. 7

\section{Daftar Pustaka}

Undang-Undang Dasar Republik Indonesia tahun 1945

Al-Mubarakfury, Syaikh Syafiyurrahman. 2014. Sirah Nabawiyah, diterjemahkan oleh Zenal Muttaqin, Bandung: Jabal.

Antonio,Muhammad Syafi'i. 2017. Bank Syariah dari Teori ke Praktek, Cet. 27, Jakarta: Gema Insani.

Dampriyanto . 2009. Undang Undang Dasar Republik Indonesia tahun 1945. Sidoarjo: Masmedia Buana Pustaka.

Harahap, Sofyan. 2002. Teori Akuntansi, Jakarta: Grafindo Persada.

Imam, Patrick dan Kangni Kpodar, "Islamic Banking : Good for growth?", Elsevier:International Journal of Economic Modelling, No.59, 2016. 
Indonesia Legal Center Publishing. 2009. Himpunan Peraturan Perundang Undang Perbankan Syariah UU RI No. 21 Tahun 2008. Cet. 1, Jakarta: Karya Gemilang.

Karim, Adiwarman A. 2009. Bank Islam Analisis fiqih dan Keuangan, ed 3, Jakarta: PT Raja Grafindo Persada.

Kassim, Salina. "Islamic Finance and Economic Growth: the Malaysian Experience”, Sciencedirect: Global Finance Jurnal, 2016.

Lebdaoui, Hind dan Joerg Wild. "Islamic Banking Presence and Economic Growth in Southeast Asia", Emerald: International Journal of Islamic and Middle Eastern Finance and Management, Vol.9, No.4, 2016, pp. 551-569

Pusat Pengkajian dan Pembangunan Ekonomi Islam. 2008. Ekonomi Islam, Jakarta: PT. Raja Grafindo Persada.

Rahardja, Prathama dan Mandala Manurung. 2004. Pengantar Ilmu Ekonomi Mikro dan Makro, Jakarta: Fak. Ekonomi UI.

Redaksi Sinar Grafika. 2005. Undang-undang Perbankan No. 10 tahun 1998. cet. 5, Jakarta: Sinar Grafika.

Riduwan dan Engkos Achmad Kuncoro. 2008. Analisis Jalur: Path Analysis, Edisi 2, Bandung: Alfabeta.

Rivai, Veithzal dan Andria Permata Veithzal. 2008. Islamic Financial Management, Jakarta: Raja Grafindo Persada.

Warde, Ibrahim. 2009. Islamic Finance keuangan Islam dalam Perekonomian Global, diterjemahkan oleh Andriyadi Ramli, Yogyakarta: Pustaka Pelajar. 